\title{
Quantitative mapping of bacterioplankton populations in seawater: field tests across an upwelling plume in Monterey Bay
}

\author{
Marcelino T. Suzuki, Christina M. Preston, Francisco P. Chavez, Edward F. DeLong*
}

Monterey Bay Aquarium Research Institute, 7700 Sandholdt Rd., PO Box 628, Moss Landing, California 95039, USA

\begin{abstract}
Few methods are available for quantifying specific prokaryotic taxa in marine plankton samples. In this study, we report a novel sampling and analysis strategy that circumvents some of the difficulties associated with current methods. This new approach allows for increased spatial, temporal and phylogenetic resolution over what has been achievable in routine bacterioplankton surveys. Picoplankton from small volume samples $(30 \mathrm{ml})$ were collected on polysulfone filters and DNA was extracted with a commercially available DNA purification kit. The contribution of different bacterioplankton members at the group and subgroup levels was quantified by 5 ' nuclease assays. Percentages of small subunit (SSU) rDNAs from SAR11, SAR86, Roseobacter, Cytophaga and Synechococcus clades in DNA extracted from small samples were compared with SSU rDNA in DNA samples extracted from 6 to 91 seawater. Only small differences were observed between the methods. The approach was also tested by estimating gene copy numbers in a seawater sample spiked with varying numbers of cells from a cultivated marine Roseobacter strain. Finally we measured SSU rDNAs from the same groups of marine bacterioplankton in samples from a rapid survey of an upwelling plume in Monterey Bay, California, USA. A strong negative correlation between the percentage of Cytophagales and recently upwelled water, and an overlap between higher SAR86 percentages and a chlorophyll a concentration peak was found. The results confirm that rapid mapping of specific bacterioplankton groups is achievable using small samples and 5' nuclease assays.
\end{abstract}

KEY WORDS: Bacterioplankton diversity · Coastal upwelling

\section{INTRODUCTION}

The use of both cultivation-based and cultivationindependent approaches has provided new perspectives on the nature of bacterioplankton communities in the sea over the past decade (Giovannoni et al. 1990, Schmidt et al. 1991, DeLong 1992, Fuhrman et al. 1993, Gonzalez \& Moran 1997, Suzuki et al. 1997). Major groups that contain cultivable members include the gamma proteobacteria (i.e., Vibrio spp., Psedoalteromonas spp. and Pseudomonas spp.), the Flexibacter, Bacteroides and Cytophaga phylum (i.e., Cytophaga spp. and Flavobacterium spp.), the Cyanobacteria (Synechococcus spp. and Prochlorococcus spp.) and

\footnotetext{
*Corresponding author. E-mail: delong@mbari.org
}

the alpha proteobacteria (i.e., Roseobacter spp. and Ruegeria spp.). In addition, cultivation-independent studies have revealed a number of novel prokaryotic groups (Britschgi \& Giovannoni 1991, DeLong 1992, Giovannoni et al. 1996, Gordon \& Giovannoni 1996, Fuhrman \& Davis 1997) that are abundant and widespread in marine pelagic ecosystems.

Despite the large number of surveys of bacterioplankton diversity, fewer studies have assessed the spatial and temporal distributions of pelagic microorganisms. Factors contributing to their distribution and diversity are not well defined. This is largely due to methodological limitations. Most quantitative estimates of the abundance of uncultured planktonic microbes have relied on quantification of ribosomal RNA by radiolabeled oligonucleotide hybridization (Gio- 
vannoni et al. 1996, Gordon \& Giovannoni 1996, Field et al. 1997, Massana et al. 1997). However, the relatively low concentration of bacterioplankton cells, as well as their low ribosomal RNA content, requires collection of large volumes of seawater (ca 2 to 10 l) for such experiments. This seriously limits the number of samples that can be processed and analyzed.

The sensitivity of in situ hybridization techniques is also affected by the low rRNA content of marine bacterioplankton cells. The recent introduction of improved protocols using cyanine fluorescent dyes (Glöckner et al. 1996) and the use of polyribonucleotide probes has improved prospects for enumeration of some uncultivated groups of marine bacterioplankton (DeLong et al. 1999, Eilers et al. 2000). However, in many instances these approaches still lack sufficient sensitivity and have not yet been adapted to high throughput methods such as flow cytometry for application in field studies.

Another class of methods to estimate the abundance of uncultivated microbes relies on the quantification of small subunit (SSU) rDNAs after PCR amplification using universal primers. Two such methods (length heterogeneity PCR, LH-PCR, and terminal restriction fragment length polymorphism, TRFLP) have been applied to the analysis of marine planktonic communities (Rappé et al. 1998, Suzuki et al. 1998, Suzuki 1999, Bernhard \& Field 2000, Gonzalez et al. 2000). The main problem with LH-PCR, TRFLP or any PCR-based method targeting SSU rDNAs universally and using end-point quantification is the possible introduction of biases, mainly by primer selection and by the 'kinetic bias' (Suzuki \& Giovannoni 1996). Approaches such as LH-PCR and TRFLP also rely on simple criteria such as fragment size for identification, which is presumptive, and often not sufficiently discriminatory for quantitative purposes, especially in complex samples.

In the present study we tested a new scheme for sampling, DNA extraction and community structure analysis that circumvents some of the problems associated with the methods described above. This sampling scheme allows a large number of samples to be collected and processed, and the percentages of a large number of marine bacterioplankton groups to be estimated in a single sample. Small samples $(30 \mathrm{ml})$ were collected on polysulfone filters, and the DNA was extracted using a commercially available, high-throughput DNA purification kit. Bacterioplankton community struc- ture was then estimated at the group and subgroup levels using a real time PCR technique (5' nuclease assays, Livak et al. 1995a) that we recently adapted for measuring rDNA from marine prokaryotes (Suzuki et al. 2000). We compared results using this new sampling and extraction method with those obtained using standard sampling techniques. We tested the method by adding known numbers of cultivated Roseobacter cells as internal standards. Finally, we applied our new sampling scheme during a rapid survey of an upwelling plume in Monterey Bay, CA, USA, to test the method for quantitative mapping of bacterioplankton groups in the field.

\section{MATERIAL AND METHODS}

Sample collection. Seawater was collected from a $5 \mathrm{~m}$ depth at 19 hydrographic stations located approximately $5 \mathrm{~km}$ apart (Fig. 1) on April 26, 2000, aboard the RV 'Western Flyer'. The stations covered an area of active upwelling that had been mapped the previous

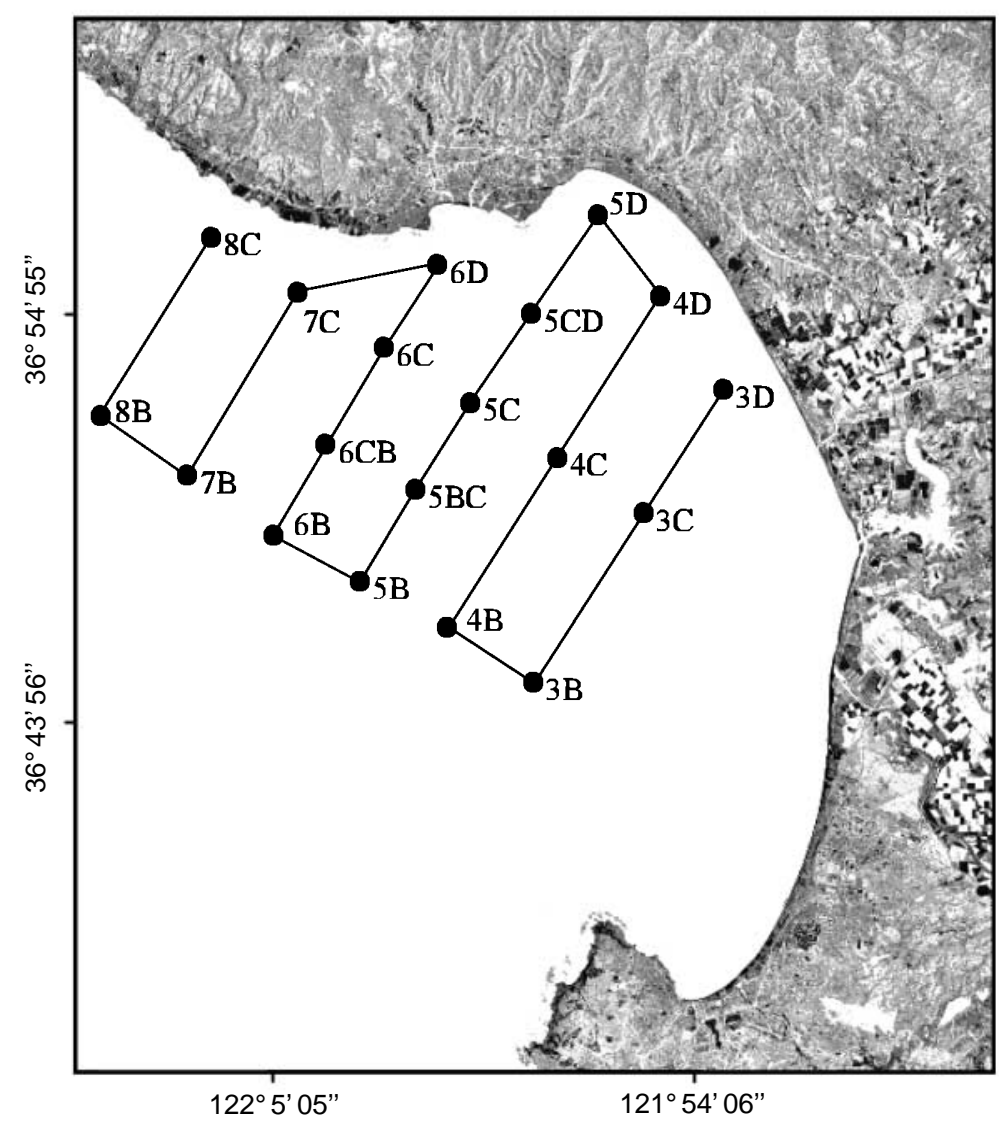

Fig. 1. Map of Monterey Bay, CA, USA, indicating the location of hydrographic stations where $5 \mathrm{~m}$ depth water samples were collected 
day. Because of the short time between stations, it was impractical to collect larger samples (over 5 l) at all stations. To test our new approach, $30 \mathrm{ml}$ water samples were pre-filtered through a $1.6 \mu \mathrm{m}$ GF-A glass fiber filter (Whatman, Maidstone, United Kingdom), and subsequently filtered through a $13 \mathrm{~mm}$ Supor200 ${ }^{\circledR}$ $0.2 \mu \mathrm{m}$ membrane (Pall Gelman Inc., Ann Arbor, MI, USA) in a Swinnex ${ }^{\circledR}$ filter holder (Millipore, Bedford, MA, USA) using a $30 \mathrm{ml}$ polypropylene syringe. The filters were placed in $600 \mu \mathrm{l}$ microcentrifuge tubes, immersed in $180 \mu \mathrm{l}$ of DNA lysis buffer $(20 \mathrm{mM}$ Tris HCL, pH 8.0, 2 mM EDTA, pH 8.0, 1.2\% Triton $\mathrm{X}$ [Fisher, Tustin, CA, USA] and $20 \mathrm{mg} \mathrm{m}^{-1}$ lysozyme [Sigma, St. Louis, MO, USA]) and stored at $-20^{\circ} \mathrm{C}$ before DNA extraction. (Alternatively, filters can be stored in $130 \mu \mathrm{l}$ buffer without lysozyme and the enzyme added just before lysis.)

To check for the introduction of significant biases in the community composition estimated from $30 \mathrm{ml}$ samples, we collected picoplankton from larger water samples in parallel from a depth profile during the same cruise. We used a standard, previously described collection procedure (Massana et al. 1997). Briefly, at Stn 4B, water samples (4 to 10 l) were collected from 5 depths (surface, $20 \mathrm{~m}, 40 \mathrm{~m}, 100 \mathrm{~m}$ and $200 \mathrm{~m}$ ) onto Sterivex ${ }^{\circledR}$ cartridges (Millipore), with prefiltration through inline GF-A (Whatman) glass fiber filters. Lysis buffer (40 mM EDTA, 50 mM Tris HCL, pH 8.0, $0.75 \mathrm{M}$ sucrose) was added to the Sterivex ${ }^{\circledR}$ cartridges that were then frozen shipboard at $-20^{\circ} \mathrm{C}$ and subsequently stored in the laboratory at $-80^{\circ} \mathrm{C}$. At the same station $30 \mathrm{ml}$ samples were collected from 11 depths (surface, 5, 10, 20, 30, 40, 60, 80, 100, 150 and $200 \mathrm{~m}$ ) as described above.

Near-surface temperature and salinity were measured underway with an SBE 21 underway mapping system (Sea-Bird Electronics, Bellevue, WA, USA) and chlorophyll a concentrations were estimated from the in situ fluorescence measured underway with a WetStar Miniature in situ fluorometer (WET Labs, Philomath, OR, USA) according to the manufacturer's specifications.

The water sample for the Roseobacter addition experiment was collected from a $200 \mathrm{~m}$ depth, $17.4 \mathrm{~km}$ west of Moss Landing, CA, USA.

DNA extraction. Filter samples were thawed and incubated in microcentrifuge tubes with $180 \mu$ lysis buffer for $1 \mathrm{~h}$ at $37^{\circ} \mathrm{C}$. Subsequently $1 \mu \mathrm{l}$ of ribonuclease I (15 Kunitz units $\mathrm{ml}^{-1}$ final concentration, Sigma) was added and the samples were incubated for $5 \mathrm{~min}$ at room temperature. Twenty-five microliters of Proteinase $\mathrm{K}\left(25 \mathrm{mg} \mathrm{ml}^{-1}\right.$ ) was added and the samples were treated according to the DNeasy ${ }^{\circledR}$ tissue kit protocol for Gram-positive bacteria (Qiagen, Valencia, CA, USA), except that DNA was eluted from the
DNeasy $^{\circledR}$ spin columns using $200 \mu$ l of TE buffer pH 8.0 instead of the buffer provided by the manufacturer.

Nucleic acids from the Sterivex ${ }^{\circledR}$ cartridges were extracted as previously described (Massana et al. 1997). The DNA extracts were then further purified using the DNeasy tissue kit (Qiagen). Briefly, $50 \mu \mathrm{l}$ of the nucleic acid crude extract was digested with $1 \mu$ of ribonuclease I (54 Kunitz units $\mathrm{ml}^{-1}$, final concentration) for $2 \mathrm{~min}$ at room temperature, $150 \mu \mathrm{l}$ TE buffer was added, and the sample was purified using the manufacturer's protocol for cultured animal cells, except that no Proteinase K was added. DNA was eluted from the DNeasy spin column using $200 \mu \mathrm{l}$ of TE buffer, $\mathrm{pH}$ 8.0. This DNA purification was necessary to remove inhibitory substances and produced DNA suitable for 5' nuclease assays (Suzuki et al. unpubl. data).

Standards for 5' nuclease assays. Details on the construction of SSU and large subunit (LSU) rDNA clones from environmental DNA (prefix MB1) and from cultivated microbes are presented elsewhere (Suzuki et al. 2000). In addition, we used clones EBAC31, EBAC37 and EBAC39, which are SSU and LSU rDNA subclones from Bacterial Artificial Chromosome clones EBAC31A08, EBAC37G09 and EBAC39D12 (Béjà et al. 2000b), respectively. The SSU and LSU rDNA was PCR amplified using the TaqPlus Precision DNA polymerase (Stratagene, La Jolla, CA, USA), as previously described (Suzuki et al. 2000) and cloned using the TOPO TA cloning ${ }^{\circledR}$ kit (Invitrogen, Carlsbad, CA, USA) following the manufacturer's protocol. The standards used for the primer and probe sets SAR11, ROSEO, CYTOP and SAR86 (Table 1) were clones MB11B07, R2A57pCRbl, MB11E04 and EBAC31, respectively. We also used EBAC31 as the standard for the assays with the BACT2 set. All plasmids were purified and linearized by digestion with the restriction endonuclease Not I as previously described (Suzuki et al. 2000). Copy numbers of all standards were estimated by $5^{\prime}$ nuclease assays relatively to copy numbers of EBAC31 using the pUC primer and probe set (Suzuki et al. 2000). Copy numbers of EBAC31 were estimated from DNA concentration measured fluorometrically by PicoGreen ${ }^{\circledR}$ (Molecular Probes, Eugene, OR, USA) staining and a FluorImager ${ }^{\mathrm{TM}}$ fluorescence imager (Molecular Dynamics, Sunnyvale, CA, USA) according to the manufacturer's specifications.

Cultivated strains. Several cultivated organisms belonging to the domains Bacteria were chosen as templates for primer specificity tests or PCR cloning. All organisms used in this study are listed in Table 2. Nucleic acids were extracted from axenic cultures by the cetyl trimethyl ammonium bromide protocol (Ausubel et al. 1988) or the DNeasy ${ }^{\circledR}$ kit according to the manufacturer's protocol for cultured bacterial cells. Genomic DNA concentrations were measured using a 


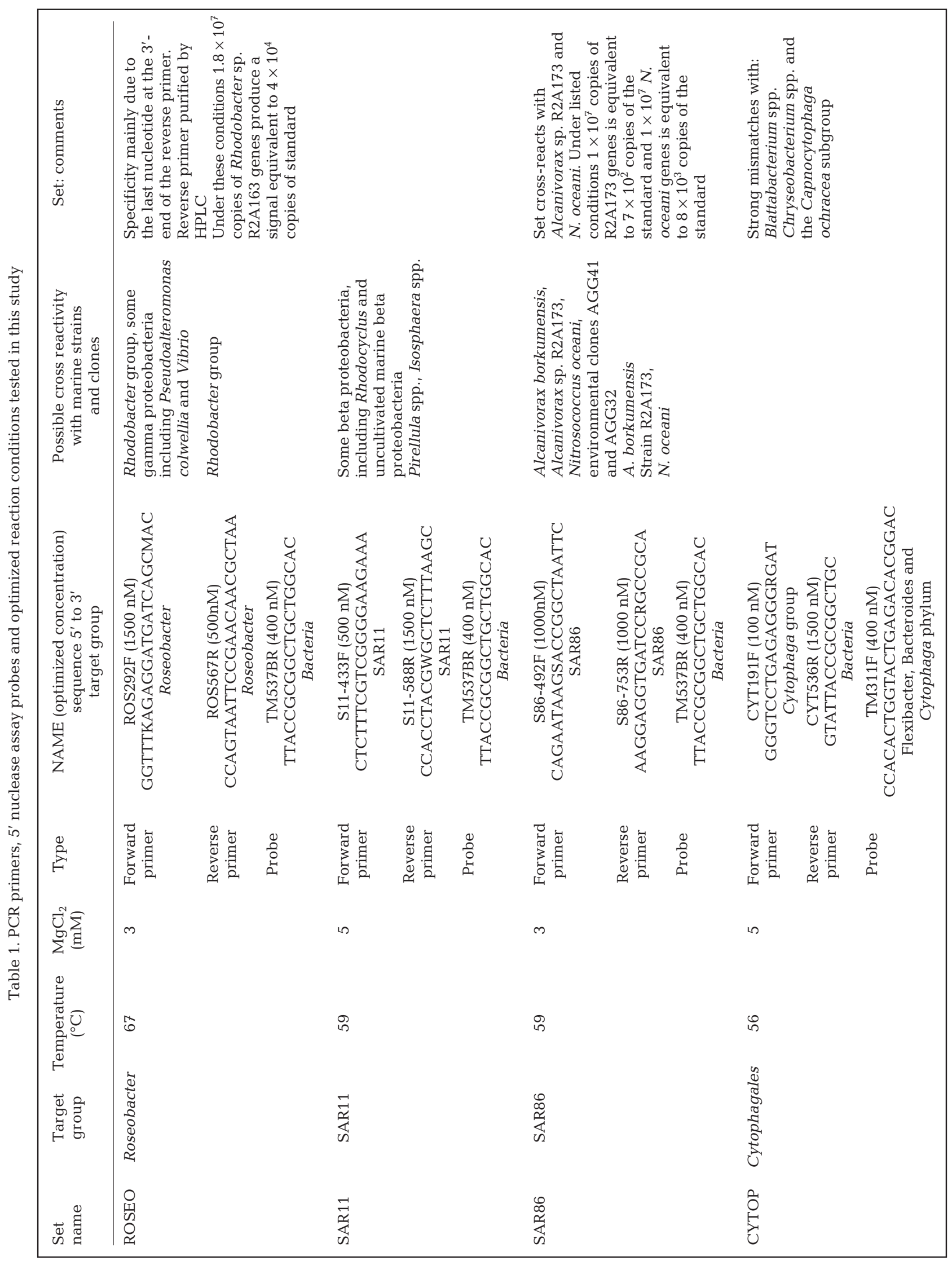


Table 2. Summary of the specificity tests. +: strong amplification; +/-: weak amplification; -: no amplification. ver: verrucomicrobiales; hgc: high $\mathrm{G}+\mathrm{C}$ Gram-positive bacteria; cya: Cyanobacteria; alp: alpha proteobacteria; gam: gamma proteobacteria; fib: Fibrobacter; fbc: Flexibacter, Bacteroides and Cytophaga phylum; Syn: Synechococcus group; Ros: Roseobacter litoralis subgroup; Par: Paracoccus subgroup; Pse: Pseudomonas subgroup; Pal: Pseudoalteromonas group; Col: Colwellia group; Oce: Oceanospirillum group; Alc: Alcanivorax and Fundibacter group; Thi: Thiobacillus group; Cyt: Cytophaga group I. Shadowed organisms/clones were used as standards for the 5' nuclease assays. Group names are according to the Ribosomal Database Project v.7.1

\begin{tabular}{|lllcccc|}
\hline \multirow{2}{*}{ Group } & \multirow{2}{*}{ Subgroup } & \multirow{2}{*}{ Organism/clone } & \multicolumn{5}{c|}{ TaqMan sets } \\
& & & ROSEO & SAR11 & SAR86 & CYTOP \\
ver & & MB11A01 & - & - & - & - \\
hgc & & MB11A03 & - & - & - & - \\
fib & & MB13C05 & - & - & - & - \\
cya & Syn & MB11A04 & - & - & - & - \\
cya & Plastids & MB11B05 & - & - & - & - \\
alp & Sar11 & MB11B07 & - & + & - & - \\
alp & Sar11 & MB21A02 & - & + & - & - \\
alp & Sar116 & EBAC39 & - & - & - & - \\
alp & Sar116 & EBAC37 & - & - & - & - \\
alp & Sar116 & MB11B3 & - & - & - & - \\
alp & Ros & R2A57 pCRbl & + & - & - & - \\
alp & Ros & R2A62 pCRII & + & - & - & - \\
alp & Par & R2A163 pCRII & $+/-$ & - & - & - \\
alp & Par & R2A117 pCRII & $+/-$ & - & - & - \\
gam & Sar86 & EBAC31 & - & - & + & - \\
gam & Pal & Moritella marina & - & - & - & - \\
gam & Col & Strain R2A81 & - & - & - & - \\
gam & Pse & Strain R2A30 & - & - & - & - \\
gam & Oce & Strain R2A148 & - & - & - & - \\
gam & Alc & R2A173 pCRII & - & - & - & - \\
gam & Thi & Nitrosococcus oceani & - & - & - & - \\
fbc & Cyt & Strain R2A103 & - & - & - & - \\
fbc & Cyt & MB11E04 & - & - & - & + \\
fbc & Cyt & Cytophaga marinoflava - & - & - & + \\
& & & & & & + \\
\hline
\end{tabular}

group (RDP tln 2.15.1.3). Finally, the bacterial set BACT2 and set PHPICO, designed to target marine Synechococcus and Prochlorococcus spp., have been previously described (Suzuki et al. 2000).

The probe (TM536BR) for the SAR11, SAR86 and ROSEO primer sets targeted the 'universal' region homologous to Escheridia coli positions 519 to 536 (Giovannoni et al. 1988), with biased specificity for the domain Bacteria. The specificity for these primer and probe sets is derived entirely from the PCR primers, and not the probe. The probe for the CYTOP set is based on the probe CF319a (Manz et al. 1996), modified with 6 extra nucleotides at the 5 ' end to increase its thermal stability to comply with the requirements for 5' nuclease assays (Livak et al. 1995b). Five prime nuclease assay primers listed in Table 1 were designed using the ARB software, provided by $\mathrm{O}$. Strunk and W. Ludwig, Technical University of Munich, Germany. A database of over 10000 SSU rRNA sequences was used to check primer specificity and possible mismatches. All probes and primers were screened and optimized for the requirements of 5 ' nuclease assays using the Primer Express $^{\odot}$ software (PE Biosystems, Foster City, CA, USA).

5' nuclease assays. Although optimized 5' nuclease assay parameters (i.e., [primers], [fluorogenic probe] and $\left[\mathrm{MgCl}_{2}\right]$ ) between different primer and probe sets varied, the following conditions were identical for all: in a final volume of $25 \mu$ reactions contained 1X Platinum $^{\circledR}$ Taq DNA polymerase buffer, $200 \mu \mathrm{M}$ of dATP, dCTP and dGTP, $400 \mu \mathrm{M}$ dUTP, 0.25 U AmpErase ${ }^{\circledR}$ Uracyl N-Glycosylase (UNG, PE Biosystems), $0.25 \mu \mathrm{l}$ 100X Blue-636 passive reference dye (MegaBases,

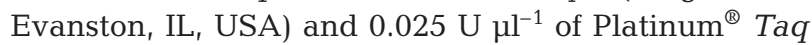
DNA polymerase (Life Technologies, Rockville, MD, USA). All reactions were set in optical tubes or reaction trays (PE Biosystems), with $2.5 \mu \mathrm{l}$ of template being delivered first into the tubes using a Microman ${ }^{\circledR}$ M10 positive displacement pipette (Rainin, Emeryville, CA, USA). A Microman ${ }^{\circledR}$ M100 positive displacement pipette (Rainin) was used to deliver $22.5 \mu$ l of a master mix and the tubes were sealed with optical caps. In experiments optimizing the effect of primer concentrations, the primers were excluded from the master mix and added last to the tubes. All reaction were per-
Marine Alpha Proteobacteria (Gonzalez \& Moran 1997). Set CYTOP was designed to target the Cytophaga 
formed in a Model 7700 Sequence Detection System (SDS, PE Biosystems), programmed with a soak step of 2 min at $50^{\circ} \mathrm{C}$, allowing the AmpErase UNG to hydrolyze previous PCR amplicons possibly carried over from previous reactions. An enzyme activation soak step of 2 min at $94^{\circ} \mathrm{C}$ followed the initial soak step. Finally, 40 cycles of $15 \mathrm{~s}$ denaturation at $94^{\circ} \mathrm{C}$ and 1 min annealing and extension at the temperatures listed in Table 1 were performed. All results were analyzed in a PowerMac 4400 (Apple Computer Co., Cupertino, CA, USA) computer using the Sequence Detector v1.6. $3^{\odot}$ software (PE Biosystems)

Optimization of $\mathbf{5}^{\prime}$ nuclease assays. Specificity: For economy and simplicity, for many primer and probe sets the same TaqMan probe was used to detect different groups of organisms (i.e., Bacteria), and we relied on the sequences of the PCR primers for specificity. To examine possible cross reactivity of the primers we initially examined the formation of PCR products after 25 cycles in 3-step PCR reactions using the genomic DNAs or SSU and LSU rDNAs cloned in plasmid vectors listed in Table 2. In a final volume of $10 \mu \mathrm{l}$, reactions contained $1 \mu \mathrm{l}$ of AmpliTaqGold 10X buffer (PE Biosystems), $0.2 \mathrm{mM}$ of dNTPs (Promega, Madison, WI, USA), $0.5 \mu \mathrm{M}$ of primers, $1.5 \mathrm{mM} \mathrm{MgCl} 2$ and $0.05 \mathrm{U}$ AmpliTaqGold DNA polymerase (PE Biosystems). The reactions were run in a PE9700 thermal cycler (PE Biosystems) at the annealing temperatures listed in Table 1. In cases where cross reactivity was observed, we also tested the extent of this cross reactivity using $5^{\prime}$ nuclease assays, and minimized this cross reactivity by optimization of $\mathrm{MgCl}_{2}$ concentration and annealing and extension temperature.

Optimization of primer melting temperature: The SSU rDNAs of a strain belonging to the Paracoccus subgroup (RDP th 2.28.1.8.1.1) of the Rhodobacter group (RDP th 2.28.1.8.1) (strain R2A163, GenBank accession number U78918) cross reacted in an endpoint PCR reaction using the ROSEO primers at $59^{\circ} \mathrm{C}$. In order to minimize non-specific amplification and maintain specific amplification, 2-step end-point PCR reactions were performed at a gradient of annealing plus extension temperatures. In a final volume of $10 \mu \mathrm{l}$, reactions contained $1 \mu \mathrm{l}$ of AmpliTaqGold 10X buffer (PE Biosystems Inc., Foster City, CA, USA), $200 \mu \mathrm{M}$ dCTP, $200 \mu \mathrm{M}$ dGTP, $400 \mu \mathrm{M}$ dUTP (PE Biosystems), $3 \mathrm{mM} \mathrm{MgCl} 2,0.1 \mathrm{ng}$ of template DNA, $0.05 \mathrm{U}$ AmpErase UNG and $0.025 \mathrm{U} \mathrm{pl}^{-1}$ of AmpliTaqGold DNA polymerase. Genomic DNA of strain R2A57 (accession number U78909) and stain R2A163 were used as target and non-target templates, respectively. The reactions were run in a Robocycler Gradient96 ${ }^{\mathrm{TM}}$ thermal cycler (Stratagene) programmed to a $15 \mathrm{~min}$ enzyme activation soak step at $94^{\circ} \mathrm{C}$ and 40 cycles of $95^{\circ} \mathrm{C}$ denaturation for $47 \mathrm{~s}$, and a gradient of 63 to $74^{\circ} \mathrm{C}$ annealing and extension for $1 \mathrm{~min} 32 \mathrm{~s}$. Five $\mu \mathrm{l}$ of the reaction products were run in a $1 \%$ agarose minigel gel stained with ethidium bromide, and the gels were scanned in a MD FSI fluorescence imager (Molecular Dynamics).

Primer concentration: Five prime nuclease assay reactions were performed using a matrix of concentrations of forward and reverse primers to seeking primer concentrations yielding minimizing threshold cycle number $\left(C_{\mathrm{T}}\right)$ values and consequently the highest amplification efficiencies. Primer concentrations ranged from 100 to $1500 \mathrm{nM}$. Annealing temperatures and $\mathrm{MgCl}_{2}$ concentrations were the same as those listed in Table 1.

5' nuclease assay: bacterioplankton DNA. To check for the presence of inhibitory substances in the samples collected on $13 \mathrm{~mm}$ Supor filters and extracted with the DNeasy kit, we performed 5' nuclease assays using the BACT2 primer and probe set with 3 dilutions (undiluted, 1:10 and 1:100) of the $5 \mathrm{~m}$ depth samples from all stations. The approach tests for linearity in the estimation of rDNA copy numbers in different dilutions, including the undiluted sample (PCR inhibition leads to non-linearity in copy number estimates). Copy numbers obtained using the set BACT2 and control EBAC31 were also used as an estimate of total copy numbers of bacterial SSU rDNAs in each sample.

Five prime nuclease assays using the SAR11, SAR86, ROSEO, CYTO and PHPICO primer and probe sets were performed on undiluted samples from all stations. Because of the relative small coefficient of variation of the 5' nuclease assays (Suzuki et al. 2000) and since we did not collect multiple $5 \mathrm{~m}$ depth samples at each station, we did not run replicate assays for these samples. The percentages of SSU rDNAs for the different target groups were calculated using the bacterial SSU rDNA copy numbers estimated only from undiluted samples. Assays for the comparison between Supor $^{\circledR}$ and Sterivex ${ }^{\circledR}$ samples were run in triplicate on undiluted samples at all depths using the same primer and probe sets as above.

Roseobacter addition experiment. To test the reliability and accuracy of our collection, extraction protocol and 5 nuclease assays we performed experiments in seawater using whole cells as internal standards. Cells of strain R2A57, a member of the Roseobacter litorallis subgroup, were grown in marine R2A media (Suzuki et al. 1997) for $2 \mathrm{~d}$ at room temperature and counted by DAPI staining (Turley 1993) before addition to the water samples. Total cell numbers for the water sample were also estimated by DAPI staining and epifluorescence microscopy. We added known numbers of strain R2A57 cells to four $50 \mathrm{ml}$ seawater samples from a $200 \mathrm{~m}$ depth that had low expected $R$. litoralis subgroup cells. 
Picoplankton samples from 1 control $50 \mathrm{ml}$ subsample as well as the 4 addition experiment samples were collected onto $13 \mathrm{~mm}$ Supor filters and the DNA was extracted using the DNeasy kit protocol described. The DNA concentration of the samples was measured fluorometrically by PicoGreen ${ }^{\mathrm{TM}}$ (FMC Bioproducts, Rockland, ME, USA) staining in a FluorImager ${ }^{\mathrm{TM}}$ fluorescence imager (Molecular Dynamics) according to the manufacturer's specifications. Five prime nuclease assays using the ROSEO primer and probe set were performed, using the plasmid R2A57pCRbl as the gene copy number standard.

\section{RESULTS}

\section{Primer and probe sets}

The primer and probe sets and their optimized reaction conditions are summarized in Table 1. Primer and probe sets SAR11 and CYTOP were specific for the targeted groups, with no cross amplification with any of the tested templates (Table 2) in end-point PCR specificity tests at 59 and $56^{\circ} \mathrm{C}$, respectively.

The ROSEO primer and probe set displayed cross reactivity with the Paracoccus subgroup of the Roseobacter group, a sister clade of the targeted group. The temperature gradient test showed that at $67^{\circ} \mathrm{C}$ there was a considerable drop in this cross hybridization. After optimization of primer concentration at $67^{\circ} \mathrm{C}$, a plasmid containing the SSU rDNA from R2A163 (a member of the Paracoccus subgroup) produced a signal 100-fold lower than the plasmid R2A57pCRbl, the standard for the ROSEO primer and probe set.

The end-point PCR specificity test for the SAR86 primer and probe set showed that there was no cross amplification with any of the tested templates at $59^{\circ} \mathrm{C}$. Since there were a number of possible $3^{\prime}$ end matches between the forward and reverse primers with Nitrosococcus oceani and Alcanivorax spp., we tested the degree of cross amplification by 5 ' nuclease assays with plasmids containing the SSU rDNA of $N$. oceani and strain R2A173 (an unnamed member of the Alcanivorax clade). The results show that the signal for these cross reacting non-target groups is more than 3 orders of magnitude lower than that for SAR86 DNA.

\section{Roseobacter addition test}

Fig. 2 illustrates that there was a linear increase in the number of copies of SSU rDNAs from the Roseobacter group as a function of the number of cells of strain R2A57 added to the water sample. The y-intercept value of 4451 indicates that Roseobacter SSU

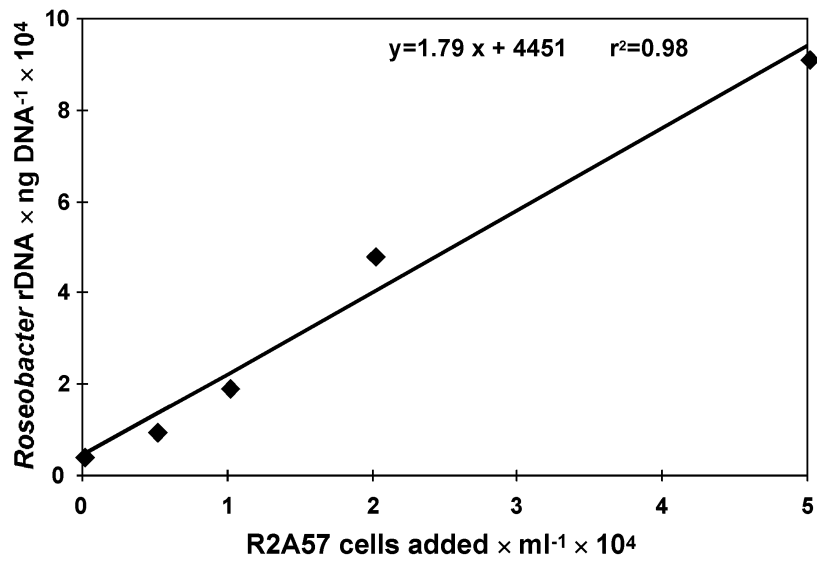

Fig. 2. Roseobacter addition experiment. Small subunit (SSU) rDNA copy numbers of the Roseobacter group were measured by a $5^{\prime}$ nuclease assay, as a function of the number of cells of strain R2A57 added to a water sample from Monterey Bay. The solid line is the regression curve described by the equation in the figure

rDNAs were present at low levels in the original $200 \mathrm{~m}$ water sample (ca $1.5 \%$ of total bacterial SSU rDNA copies). This is not surprising, since this group is highly represented in surface samples in this region.

\section{Comparison of collection and extraction methods}

Our results of the comparison of the collection and extraction methods are presented in Fig. 3. In general there was good agreement between the percentage of bacterial SSU rDNA for the 5 groups of marine bacterioplankton tested. The larger number of samples taken on Supor filters allowed a better resolution of features such as depth maxima. However, since the total biomass collected in the $13 \mathrm{~mm}$ Supor ${ }^{\circledR}$ filters was about 100 -fold lower than that collected in Sterivex ${ }^{\circledR}$ filters, the total number of Bacteria SSU rDNA copies was lower. These lower copy numbers may explain the larger standard deviations estimated by the 5 ' nuclease assays for smaller samples and consequently the large standard deviations of the percentage of the different groups of marine bacterioplankton. Finally, the relative percentage of SAR11 SSU rDNAs was consistently higher in samples collected in Supor ${ }^{\circledR}$ filters than in those collected in Sterivex ${ }^{\circledR}$ filters, although the general trends and the presence of a deep subsurface maximum at 20 to $30 \mathrm{~m}$ was maintained.

\section{Bacterioplankton distribution}

The spatial distribution of 5 major groups of marine bacterioplankton at $5 \mathrm{~m}$ during an upwelling event in 


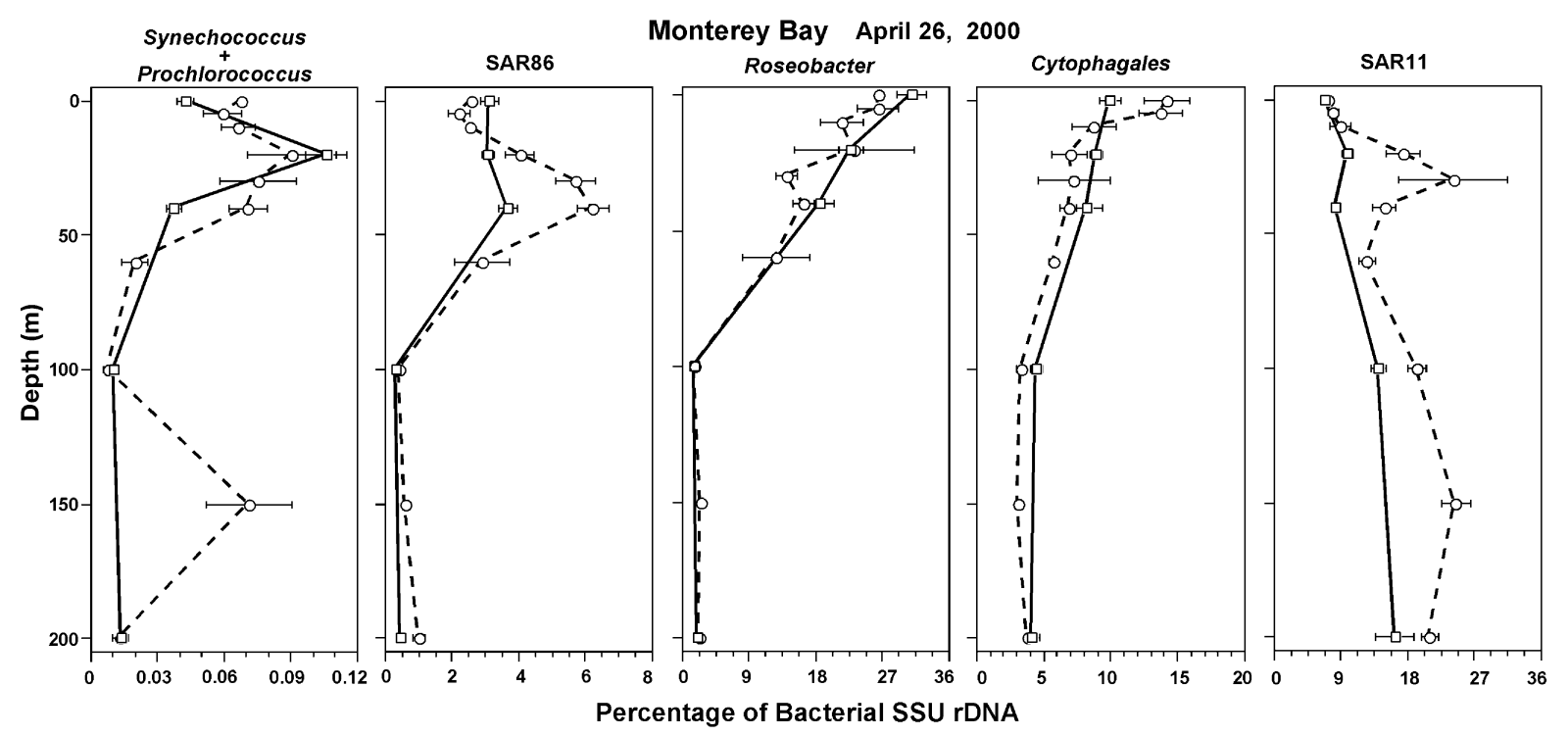

Fig. 3. Comparison between the sampling and extraction methods for genomic DNA. Depth profiles of SSU rDNAs from bacterioplankton groups are expressed as a percentage of the total SSU rDNAs from the domain Bacteria in Monterey Bay. DNA was extracted from Sterivex cartridges (solid lines) and from $13 \mathrm{~mm}$ Supor membranes (dashed lines)

Monterey Bay is shown in Fig. 4. A detailed description of the upwelling event will be published elsewhere (K. S. Johnson unpubl. data). Although a limited number of stations and environmental parameters were sampled, several correlations were observed between the percentage of SSU rDNAs from several bacterial groups and some of the hydrographic parameters measured. A comparison of Fig. 4B \& D shows a distinctive negative correlation between salinity and the percentage of SSU rDNAs from the Cytophagales, with the lowest percentages in the core of the upwelling plume (Stns 8C, 6CB and 5BC) and higher percentages both offshore and inshore of the plume. Fig. 4C \& E show an overlap of the maximal percentage of SAR86 SSU rDNAs and 1 of the peaks of chlorophyll a concentration at Stns 6C and 5CD. A similar correlation was also observed in samples from a time series at Monterey Bay (Suzuki et al. unpubl. data). The percentage of SAR11 and Roseobacter group SSU rDNAs (Fig. 4F \& G) were more homogeneous in the sampling area and showed a tendency to increase at offshore stations, west of the high salinity region, and decrease at the inshore stations. Finally, the percentages of Synechococcus and Prochlorococcus were 2 orders of magnitude lower than those of the remaining groups, and considerably lower than percentages observed in samples from a time series at Monterey Bay (Suzuki et al. unpubl. data). The distribution of Synechococcus and Prochlorococcus show higher values at stations with temperatures between 12 and $13.5^{\circ} \mathrm{C}$.

\section{DISCUSSION}

A new strategy has been successfully developed and tested for rapid and small-scale sampling and analysis of SSU rDNAs from marine bacterioplankton. Although the method does not provide real time data, it offers significant improvements over previous methods for quantifying specific bacterioplankton groups, since large numbers of samples can be analyzed, providing much greater spatial and temporal resolution. The distribution of groups surveyed in the present study at 19 stations was available within days of sample collection.

The results of the Roseobacter addition experiment, as well as comparisons of the depth distribution of different bacterioplankton groups measured using this new and published collection and extraction procedures (Massana et al. 1997), were favorable. One difference was the consistently higher percentage of SAR11 in samples collected and extracted from $13 \mathrm{~mm}$

Fig. 4. Surface distribution of oceanographic parameters. (A) Temperature $\left({ }^{\circ} \mathrm{C}\right) ;(\mathrm{B})$ salinity (PSU); (C) chlorophyll (mg $\left.\mathrm{m}^{-3}\right)$ and bacterioplankton SSU rDNAs, expressed as the percentage of total bacterial SSU rDNAs; (D) cytophagales; (E) SAR86; 
Temperature ${ }^{\circ} \mathrm{C}$

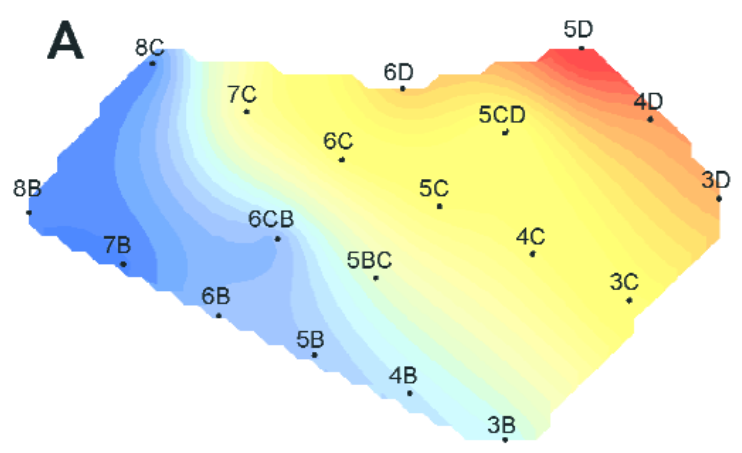

Chlorophyll $\left(\mathrm{mg} / \mathrm{m}^{3}\right)$
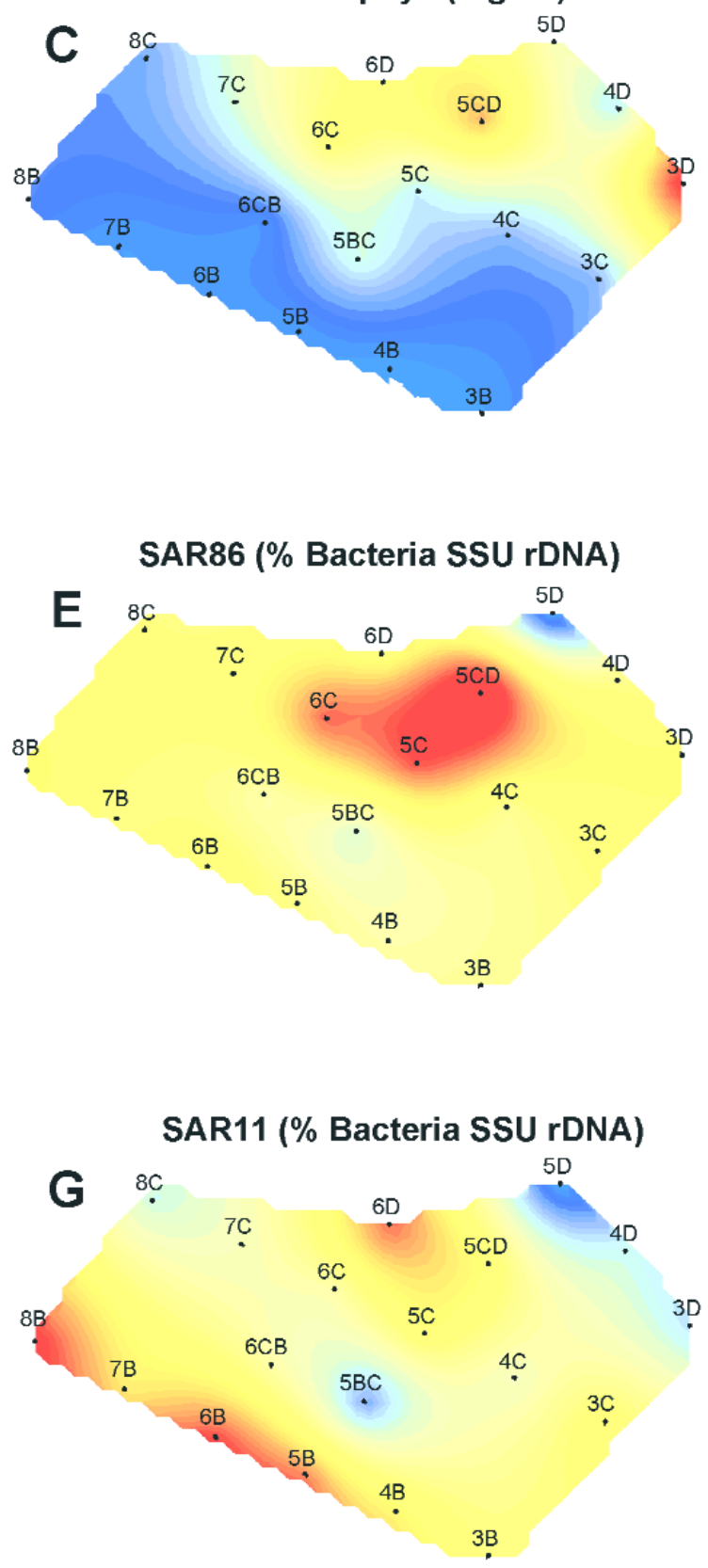
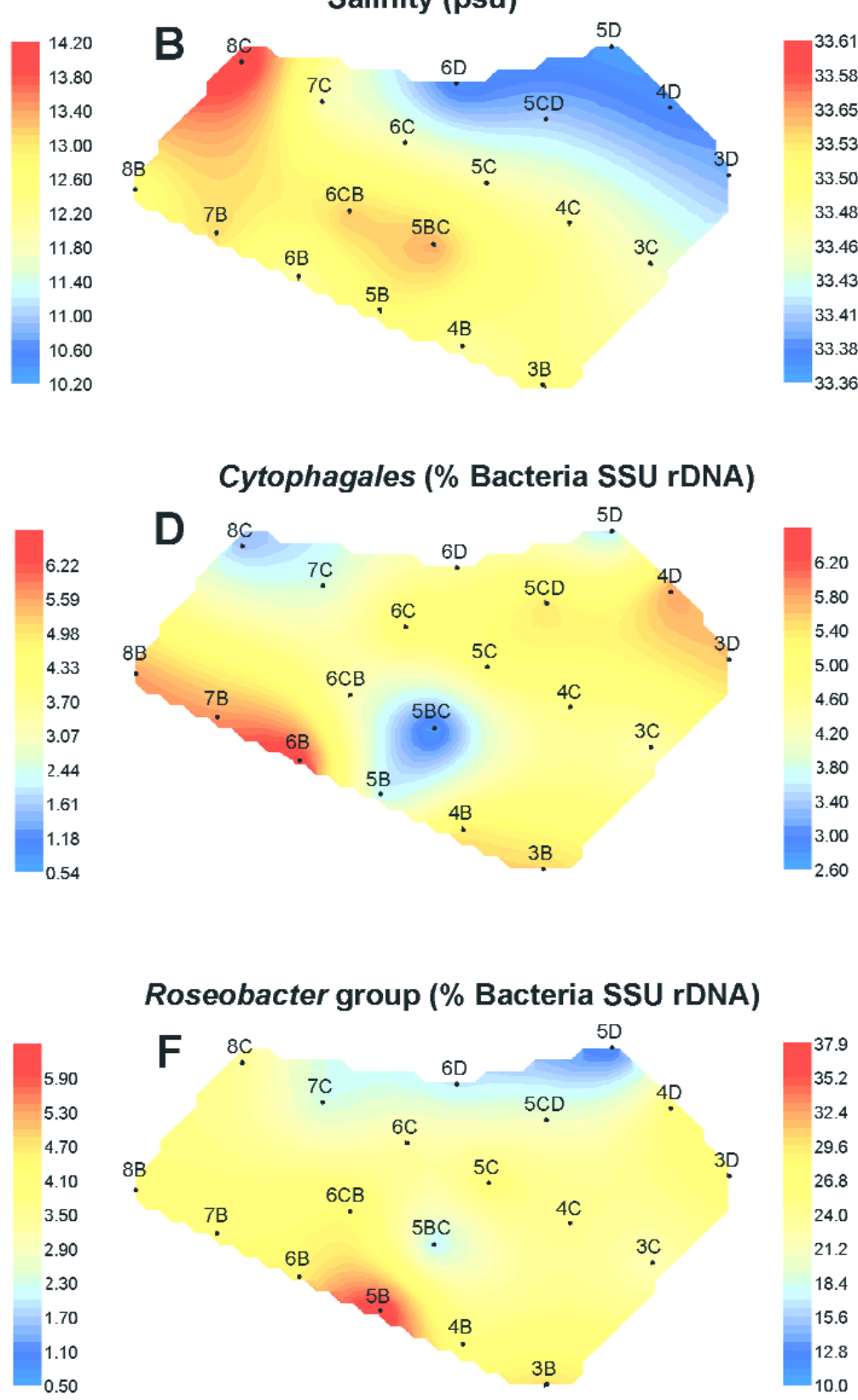

Synechococcus + Prochlorococcus (\% Bacteria SSU rDNA)

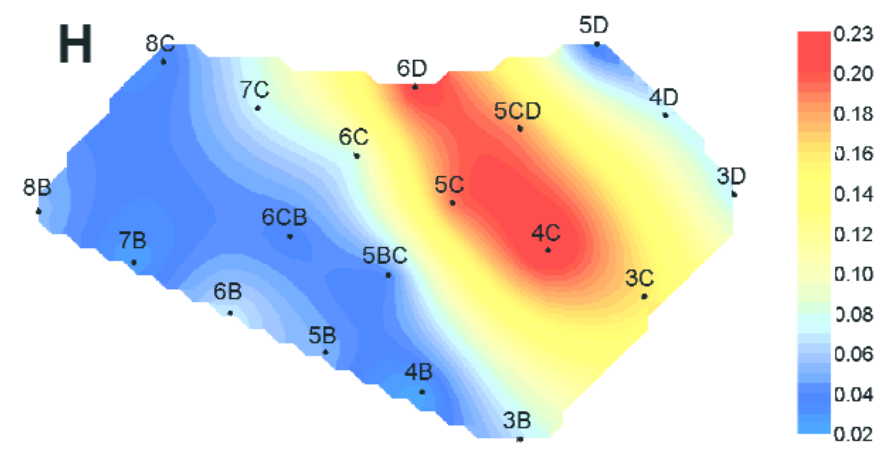


Supor $^{\circledR}$ filters compared with those obtained from Sterive ${ }^{\circledR}$ filters. This difference may be due to higher overall extraction efficiencies from this group on filters loaded with less total biomass. For sampling and processing, this new approach has several advantages. These include the facilitation of more rapid sampling procedures, increase in sample number, speed in processing and parallel processing of many samples. Disadvantages are mainly the smaller total biomass, and the requirement of collection of separate DNA and RNA samples.

The similarities in the distributions of some of the SSU rDNAs surveyed and hydrographic parameters illustrate the utility of our new method for the study of the ecology of coastal bacterioplankton populations. The negative correlation of Cytophaga and salinity, a proxy for recently upwelled water, was notable. Members of the Cytophaga group have been found associated with marine macroaggregates (DeLong et al. 1993) and were dominant during the decay of a phytoplankton bloom in a mesocosm experiment (Riemann et al. 2000). It is likely that this group of organisms becomes more important as upwelled water ages and phytoplankton bloom and then decay.

A second interesting correlation was found between levels of SAR86 percentages and chlorophyll a concentrations. This correlation has also been observed in a time series at Stn M1 in Monterey Bay (Suzuki et al. unpubl. data). The SAR86 genome has recently been shown to encode proteorhodopsin, a light driven proton pump (Béjà et al. 2000a) related to bacteriorhodopsin. The increase in relative abundance of SAR86 SSU rDNAs as a function of chlorophyll a might reflect a heterotrophic response to increases in particulate and dissolved organic matter. In this case, the light driven proton pump would provide an additional source of energy. Alternatively, the SAR86 group may be photoautotrophic, being stimulated by macronutrients $\left(\mathrm{NO}_{3}\right.$ and $\mathrm{PO}_{4}$ ) in recently upwelled water, in a fashion similar to chlorophyll a containing photoautotrophs.

The small scale $(\mathrm{km})$ heterogeneity in microbial communities observed during the survey of an upwelling plume in Monterey Bay (Fig. 4) emphasizes the need for methods of rapid enumeration of microbial populations. The ability to rapidly collect and process small samples is especially critical for monitoring microbial populations in spatially heterogeneous and temporally dynamic ecosystems such as the coastal ocean. Flow cytometry is one of few methods used for rapid picoplankton monitoring, but this technique is limited to autofluorescent or total bacterioplankton stained with DNA stains (Buck et al. 1996). The new method we describe here can potentially be applied to many marine picoplankton groups, with a much higher degree of spatial, temporal and phylogenetic resolu- tion than other available methods. Recent improvements to this method have recently allowed simultaneous extraction 96 DNA samples, with absolute quantification of SSU rDNAs (Suzuki et al. unpubl. data). Slight modifications of the approach described here have also allowed quantification of cDNAs produced from mRNA and rRNA by reverse transcription. This allows the estimation of the relative levels of gene expression in different samples (Suzuki et al. unpubl. data). In the future, by using these methods it will be possible to estimate not only the spatial and temporal microbial distributions but also the relative levels of expression of functionally important genes that may serve as proxies of metabolic activity.

Acknowledgements. We would like to thank the David and Lucile Packard foundation for a grant to MBARI that supported this study. We also would like to thank the crews of the RVs 'Western Flyer' and 'Point Lobos', and Dr Tim Pennington for their help during sampling. Dr Carmen Castro and M. Sc. Brian Schlining helped us to produce the surface plots and M. Sc. D. J. Osborn helped on the analysis of the CTD data.

\section{LITERATURE CITED}

Ausubel FA, Brent R, Kingston RE, Moore DD, Smith JA, Seidman JG, Struhl K (1988) Current protocols in molecular biology. John Wiley \& Sons Inc, New York

Béjà $\mathrm{O}$, Aravind L, Koonin EV, Suzuki MT, Hadd A, Nguyen LP, Jovanovich SB, Gates CM, Feldman RA, Spudich JL, Spudich EN, DeLong EF (2000a) Bacterial rhodopsin: evidence for a new type of phototrophy in the sea. Science 289:1902-1906

Béjà O, Suzuki MT, Koonin EV, Aravind L, Hadd A, Nguyen LP, Villacorta R, Amjadi M, Garrigues C, Jovanovich SB, Feldman RA, DeLong EF (2000b) Construction and analysis of bacterial artificial chromosome libraries from a marine microbial assemblage. Environ Microbiol 2:516-529

Bernhard AE, Field KG (2000) Identification of nonpoint sources of fecal pollution in coastal waters by using hostspecific 16S ribosomal DNA genetic markers from fecal anaerobes. Appl Environ Microbiol 66:1587-1594

Britschgi TB, Giovannoni SJ (1991) Phylogenetic analysis of a natural marine bacterioplankton population by rRNA gene cloning and sequencing. Appl Environ Microbiol 57: $1707-1713$

Buck KR, Chavez FP, Campbell L (1996) Basin-wide distributions of living carbon components and the inverted trophic pyramid of the central gyre of the North Atlantic Ocean, Summer 1993. Aquat Microb Ecol 10:283-298

DeLong EF (1992) Archaea in coastal marine environments. Proc Natl Acad Sci USA 89:5685-5689

DeLong EF, Franks DG, Alldredge AL (1993) Phylogenetic diversity of aggregate-attached vs. free-living marine bacterial assemblages. Limnol Oceanogr 38:924-934

DeLong EF, Taylor LT, Marsh TL, Preston CM (1999) Visualization and enumeration of marine planktonic Archaea and Bacteria by using polyribonucleotide probes and fluorescent in situ hybridization. Appl Environ Microbiol 65: 5554-5563

Eilers H, Pernthaler J, Glockner FO, Amann R (2000) Culturability and in situ abundance of pelagic bacteria from the North Sea. Appl Environ Microbiol 66:3044-3051 
Field KG, Gordon D, Wright T, Rappe M, Urback E, Vergin K, Giovannoni SJ (1997) Diversity and depth-specific distribution of SAR11 cluster rRNA genes from marine planktonic bacteria. Appl Environ Microbiol 63:63-70

Fuhrman JA, Davis AA (1997) Widespread Archaea and novel Bacteria from the deep sea as shown by 16S rRNA gene sequences. Mar Ecol Prog Ser 150:275-285

Fuhrman JA, McCallum K, Davis AA (1993) Phylogenetic diversity of subsurface marine microbial communities from the Atlantic and Pacific oceans. Appl Environ Microbiol 59:1294-1302

Giovannoni SJ, DeLong EF, Olsen GJ, Pace NR (1988) Phylogenetic group-specific oligodeoxynucleotide probes for identification of single microbial cells. J Bacteriol 170: $720-726$

Giovannoni SJ, Britschgi TB, Moyer CL, Field KG (1990) Genetic diversity in Sargasso Sea bacterioplankton. Nature 345:60-63

Giovannoni SJ, Rappe MS, Vergin KL, Adair NL (1996) 16S rRNA genes reveal stratified open ocean bacterioplankton populations related to the green non-sulfur bacteria. Proc Natl Acad Sci USA 93:7979-7984

Glöckner FO, Amann R, Alfreider A, Pernthaler J, Psenner R, Trebesius K, Schleifer KH (1996) An in situ hybridization protocol for detection and identification of planktonic bacteria. Syst Appl Microbiol 19:403-406

Gonzalez JM, Moran MA (1997) Numerical dominance of a group of marine bacteria in the alpha-subclass of the class Proteobacteria in coastal seawater. Appl Environ Microbiol 63:4237-4242

Gonzalez JM, Simo R, Massana R, Covert JS, Casamayor EO, Pedros-Alio C, Moran MA (2000) Bacterial community structure associated with a dimethylsulfoniopropionateproducing North Atlantic algal bloom. Appl Environ Microbiol 66:4237-4246

Gordon DA, Giovannoni SJ (1996) Detection of stratified microbial populations related to Chlorobium and Fibrobacter species in the Atlantic and Pacific oceans. Appl Environ Microbiol 62:1171-1177

Livak KJ, Flood SJ, Marmaro J, Giusti W, Deetz K (1995a) Oligonucleotides with fluorescent dyes at opposite ends provide a quenched probe system useful for detecting PCR product and nucleic acid hybridization. PCR Methods Appl 4:357-362

Livak KJ, Marmaro J, Flood S (1995b) Guidelines for designing Taqman fluorescent probes for 5'-nuclease assays. PE Applied Biosystems, Foster City

Maidak BL, Cole JR, Parker CT Jr, Garrity GM, Larsen N, Li B, Lilburn TG, McCaughey MJ, Olsen GJ, Overbeek R, Pramanik S, Schmidt TM, Tiedje JM, Woese CR (1999) A new version of the RDP (Ribosomal Database Project). Nucleic Acids Res 27:171-173

Editorial responsibility: Dittmar Hahn,

Newark, New Jersey, USA
Manz W, Amann R, Ludwig W, Vancanneyt M, Schleifer KH (1996) Application of a suite of 16S rRNA-specific oligonucleotide probes designed to investigate bacteria of the phylum cytophaga-flavobacter-bacteroides in the natural environment. Microbiology 142:1097-1106

Massana R, Murray AE, Preston CM, DeLong EF (1997) Vertical distribution and phylogenetic characterization of marine planktonic Archaea in the Santa Barbara Channel. Appl Environ Microbiol 63:50-56

Mullins TD, Britschgi TB, Krest RL, Giovannoni SJ (1995) Genetic comparisons reveal the same unknown bacterial lineages in Atlantic and Pacific bacterioplankton communities. Limnol Oceanogr 40:148-158

Rappé MS, Kemp PF, Giovannoni SJ (1997) Phylogenetic diversity of marine coastal picoplankton 16S rRNA genes cloned from the continental shelf off Cape Hatteras, North Carolina. Limnol Oceanogr 42:811-826

Rappé MS, Suzuki MT, Vergin KL, Giovannoni SJ (1998) Phylogenetic diversity of ultraplankton plastid small-subunit rRNA genes recovered in environmental nucleic acid samples from the Pacific and Atlantic coasts of the United States. Appl Environ Microbiol 64:294-303

Riemann L, Steward GF, Azam F (2000) Dynamics of bacterial community composition and activity during a mesocosm diatom bloom. Appl Environ Microbiol 66:578-587

Schmidt TM, DeLong EF, Pace NR (1991) Analysis of a marine picoplankton community by $16 \mathrm{~S}$ rRNA gene cloning and sequencing. J Bacteriol 173:4371-4378

Suzuki M, Rappe MS, Giovannoni SJ (1998) Kinetic bias in estimates of coastal picoplankton community structure obtained by measurements of small-subunit rRNA gene PCR amplicon length heterogeneity. Appl Environ Microbiol 64:4522-4529

Suzuki MT (1999) Effect of protistan bacterivory on coastal bacterioplankton diversity. Aquat Microb Ecol 20:261-272

Suzuki MT, Giovannoni SJ (1996) Bias caused by template annealing in the amplification of mixtures of 16S rRNA genes by PCR. Appl Environ Microbiol 62:625-630

Suzuki MT, Rappé MS, Haimberger ZW, Winfield H, Adair N, Ströbel J, Giovannoni SJ (1997) Bacterial diversity among small-subunit rRNA gene clones and cellular isolates from the same seawater sample. Appl Environ Microbiol 63: 983-989

Suzuki MT, Taylor LT, DeLong EF (2000) Quantitative analysis of small-subunit rRNA genes in mixed microbial populations using 5' nuclease assays. Appl Environ Microbiol 66:4605-4614

Turley CM (1993) Direct estimates of bacterial numbers in seawater samples without incurring cell loss during cell storage. In: Kemp PF, Sherr BF, Sherr EB, Cole JJ (eds) Handbook of methods in aquatic microbial ecology. Lewis Publ, Boca Raton, p 143-147

Submitted: October 7, 2000; Accepted: January 29, 2001

Proofs received from author(s): April 6, 2001 